\title{
Tanggung Gugat Kontraktor dalam Kegagalan Bangunan
}

\author{
Yushar \\ yushar.adhyaksa@gmail.com \\ Universitas Airlangga
}

\begin{abstract}
In the infrastructure procurement, of course there will be a selection of construction service providers, either through direct appointment or auction. However, construction services related to infrastructure development not always go according to plan. Sometimes there are obstacles in the building failure. In the building failure, there will definitely be a party injured. Related to the loss, it must be known who is the party responsible for the loss and how the limits of the responsibilities of the contractor implementing the construction services in the building failure. This study has two purposes: first, to find out the legal relationship between service providers and service users in construction service contracts. Secondly, to find out about building failures and their legal consequences. This study is a normative research which uses two approaches: the statute approach and the conceptual approach. The result of this study is in the event of a building failure, the failure must be revisited due to whose fault. However, if the type of contract used is a lumsum contract which means that the contractor accepts to bear all the risks that occur, then the contractor must be held accountable for the failure of the building that occurs in accordance with the provisions of Article 27 Paragraph (3) of Presidential Regulation Number 16 of 2018 concerning Procurement Government Goods / Services.

Keywords: Infrastructure; Contractor; Construction Contract; Building Failure; Liability.
\end{abstract}

\begin{abstract}
Abstrak
Dalam pengadaan infrastruktur tentunya akan dilakukan pemilihan penyedia jasa konstruksi, baik melalui penunjukan langsung maupun lelang. Namun, pengerjaan jasa konstruksi terkait dengan pembangunan infrastruktur tak selalu berjalan sesuai rencana. Terkadang terdapat kendala berupa kegagalan bangunan. Dalam hal terjadinya kegagalan bangunan, maka pasti akan ada pihak yang dirugikan. Terkait dengan adanya kerugian tersebut, haruslah diketahui siapa pihak yang bertanggung gugat atas kerugian tersebut dan bagaimana batasan tanggung jawab dari kontraktor pelaksana Jasa konstruksi dalam hal terjadi kegagalan bangunan. Penelitian ini memiliki dua tujuan, yaitu pertama untuk mengetahui hubungan hukum antara penyedia jasa dengan pengguna jasa dalam kontrak jasa konstruksi. Kedua, untuk mengetahui tentang kegagalan bangunan dan akibat hukumnya. Penelitian ini merupakan penelitian normatif yang menggunakan dua pendekatan, yaitu, pendekatan perundang-undangan dan pendekatan konseptual. Hasil dari penilitian ini adalah dalam hal terjadi kegagalan bangunan, maka harus dilihat kembali kegagalan tersebut disebabkan atas kesalahan siapa. Namun, apabila jenis kontrak yang digunakan adalah kontrak Lumsum yang berarti pihak Kontraktor menerima untuk menanggung segala risiko yang terjadi, maka kontraktor yang harus bertanggung gugat atas kegagalan bangunan yang terjadi sesuai dengan ketentuan Pasal 27 ayat (3) Peraturan Presiden Nomor 16 Tahun 2018 tentang Pengadaan Barang/Jasa Pemerintah.
\end{abstract}

Kata Kunci: Infrastuktur; Kontraktor; kontrak kerja konstruksi; kegagalan bangunan; tanggung gugat.

\section{Pendahuluan}

Kebutuhan akan jasa konstruksi semakin meningkat sebagai salah satu kegiatan yang memiliki peranan penting guna mencapai berbagai sarana guna 
menunjang terwujudnya tujuan Pembangunan Nasional yang sedang digencarkan oleh pemerintah, salah satunya pada pembangunan jalan tol. Bahwa Rencana Pembangunan Jangka Menengah Nasional 2015-2019 (RPJMN 2015-2019) menyatakan pembangunan infrastruktur di Indonesia ditujukan untuk memperkuat pembangunan konektivitas nasional yang adil dan mempercepat penyediaan infrastruktur. ${ }^{1}$ Untuk mewujudkan pembangunan infrastruktur yang hendak dicapai tentu tidak terlepas dengan adanya kesiapan perundang-undangan, peraturan pelaksana, institusi yang menangani dan perlindungan pelaksanaan pembangunan melalui kontrak yang menjadi dasar kesepakatan kontraktual. ${ }^{2}$ Umumnya kontrak pembangunan tidak terlepas dengan pembangunan konstruksi. ${ }^{3}$

Jasa Konstruksi sendiri didefinisikan dalam Pasal 1 angka 1 Undang-Undang Nomor 2 Tahun 2017 tentang Jasa Konstruksi sebagai layanan jasa konsultansi konstruksi dan/atau pekerjaan konstruksi. Pembangunan jalan tol tentunya masuk ke dalam kegiatan Pengadaan Barang/Jasa Pemerintah. Sebagaimana diatur dalam Peraturan Presiden Nomor 16 tahun 2018, kegiatan pengadaan barang/jasa pemerintah dapat dilakukan secara swakelola ataupun melalui penyedia barang/jasa. Dalam pasal 1 angka 23 Peraturan Presiden Nomor 16 tahun 2018 dijelaskan bahwa pengadaan secara swakelola adalah proses pengadaan dengan cara memperoleh barang/jasa yang dikerjakan sendiri oleh Kementerian/Lembaga/Perangkat Daerah, Kementerian/ Lembaga/PerangkatDaerahlain, organisasi kemasyarakatan, ataukelompok masyarakat, sedangkan dalam pasal 1 angka 23 Peraturan Presiden Nomor 16 tahun 2018 dijelaskan bahwa pengadaan barang/jasa pemerintah melalui penyedia adalah proses pengadaan barang/jasa pemerintah dengan cara memperoleh barang/jasa yang disediakan oleh Pelaku Usaha, baik yang berbadan hukum maupun yang tidak berbadan hukum.

Proyek pembangunan jalan tol adalah kegiatan pengadaan yang tentu nilainya sangat besar, sehingga umumnya pemilihan penyedia dilakukan dengan cara tender,

\footnotetext{
${ }^{1}$ Dwi Mariyati, 'Prinsip Hukum Dalam Penyusunan Dan Pelaksanaan Kontrak Engineering Procurement Construction (Kontrak "EPC”)" (2018) 33 Yuridika.[189].

2 ibid.[189].

3 ibid.[189].
} 
kecuali dalam keadaan tertentu akan dilakukan penunjukan langsung. Untuk melakukan pembangunan bidang konstruksi, dilakukan pembuatan kontrak antara pengguna jasa (bouwheer) dengan penyedia jasa (kontraktor) dimana kontrak tersebut untuk melaksanakan pekerjaan konstruksi yang memberikan layanan jasa pelaksanaan dalam pekerjaan konstruksi yang memberikan layanan jasa pelaksanaan dalam pekerjaan konstruksi yang meliputi rangkaian kegiatan atau bagian-bagian kegiatan mulai dari penyiapan lapangan sampai dengan penyerahan akhir hasil pekerjaan konstruksi yang didasari dengan penyerahan akhir hasil pekerjaan konstruksi yang didasari dengan kesepakatan para pihak agar kontrak konstruksi tersebut disepakati sesuai dengan perjanjian yang sah sebagaimana diatur dalam pasal 1320 BW yaitu "untuk sahnya perjanjian diperlukan syarat sepakat mereka yang mengikatkan dirinya". Kontrak pengerjaan proyek bangunan antara penggunaan jasa dengan kontraktor dikenal dengan kontrak konstruksi. Di dalam kontrak konstruksi tersebut biasanya terdapat pengaturan tanggung jawab dari kontraktor yang meliputi tanggung jawab terhadap hasil pekerjaan. Apabila jasa (kontraktor) lalai dalam mengerjakan tugasnya untuk melaksanakan pekerjaan konstruksi maka pihak pengguna jasa (bouwheer) dapat meminta pertanggungjawaban ganti rugi atau dituntut secara hukum.

Dalam Pasal 1 angka 8 Undang-undang Nomor 2 Tahun 2017 Tentang Jasa Konstruksi disebutkan bahwa Kontrak Kerja Konstruksi adalah keseluruhan dokumen kontrak yang mengatur hubungan hukum antara Pengguna Jasa dan Penyedia Jasa dalam penyelenggaraan Jasa Konstruksi. Sejauh ini, cukup sering terjadi kerusakan dalam pembangunan jalan tol, yaitu kegagalan bangunan. Salah satu hal yang menjadi penyebab dari keadaan ini adalah seringnya dalam pengerjaan konstruksi tersebut terdapat hambatan yang timbul di luar prediksi para pihak dan diikuti dengan sulitnya mengubah isi kontrak kerja konstruksi yang berujung pada penurunan kualitas bangunan.

Seringnya terjadi keadaan hasil pekerjaan konstruksi yang tidak seusai dengan spesifikasi pekerjaan sebagaimana disepakati dalam kontrak kerja konstruksi baik sebagian maupun keseluruhan sebagai akibat dari kesalahan pengguna jasa atau 
penyedia jasa (kontraktor) merupakan faktor yang tidak kalah penting dalam melindungi hak-hak para pihak yang dirugikan sehingga kedudukan tanggung gugat dalam kontrak konstruksi merupakan hal yang esensial dalam adanya kegagalan bangunan untuk meminimalisir risiko-risiko kerugian diantara para pihak.

Dalam kontrak konstruksi terdapat kontrak rancang bangun atau turn key dimana dalam kontrak ini aspek tugas perencanaan dan pelaksanaan proyek sekaligus dilakukan oleh satu kontraktor. Maka dengan demikian konsultan perencana tidak mendapatkan tugas dari Pengguna Jasa, tetapi menerima tugas dari Penyedia Jasa atau Kontraktor. Dalam hal ini jika terjadi kegagalan bangunan baik yang diakibatkan kesalahan perencana maupun kesalahan pelaksanaan proyek maka yang bertanggung jawab adalah Kontraktor utama tersebut. ${ }^{4}$ Sebenarnya penumpukan pembagian tugas seperti jenis Kontrak Konstruksi ini tidak dibenarkan karena dikhawatirkan terjadi perbenturan kepentingan. Kemudian pada jenis kontrak konstruksi Konvensional tugas perencanaan dilakukan terpisah dari tugas pelaksanaan yang dilakukan oleh Kontraktor, jadi pengguna jasa membuat kontrak terpisah antara kontrak pelaksanaan proyek dengan perencanaan proyek. Kontrak perencanaan proyek dilakukan oleh pengguna jasa dengan perusahaan Perencanaan Teknik. $^{5}$ Jika terjadi kegagalan bangunan yang diakibatkan kesalahan perencana maka yang bertanggung jawab adalah Konsultan Perencana saja. Dengan demikian perlu diteliti lebih jauh terkait Tanggung Gugat Kontraktor atas kegagalan bangunan.

\section{Hubungan Hukum antara Penyedia Jasa dengan Pengguna Jasa dalam Kontrak Jasa Konstruksi}

Overeenkomst diterjemahkan dalam bahasa Indonesia sebagai perjanjian. ${ }^{6}$ Subekti mendefinisikan perjanjian sebagai suatu peristiwa dimana seorang berjanji kepada orang lain atau dimana 2 (dua) orang itu saling berjanji untuk melakukan

\footnotetext{
4 H. Nazarkhan Yasin, Mengenal Kontrak Konstruksi Di Indonesia (Gramedia 2006).[55].

5 ibid.[55].

${ }^{6}$ Hasanuddin Rahman, Contract Drafting (Citra Aditya Bhakti 2003).[2].
} 
suatu hal. ${ }^{7}$ Perjanjian sendiri didefinisikan dalam Pasal 1313 BW sebagai perbuatan di mana satu orang atau lebih mengikatkan diri terhadap satu orang latau lebih yang lain. Pendefinisian berdasar 1313 BW ini lah yang membuat perjanjian tidak dapat disamakan dengan kontrak, yaitu dalam Pasal 1313 BW tidak memuat unsur "dibuat secara tertulis dan terstruktur". 8

Dalam hukum perjanjian berlaku suatu asas-asas di antaranya :

1. Asas Kebebasan Berkontrak yang diatur dalam Pasal 1338 ayat (1), Yang berbunyi "Semua perjanjian yang dibuat secara sah berlaku sebagai undangundang bagi mereka yang membuatnya". Dengan menekankan pada perkataan semua, maka pasal tersebut seolah-olah berisikan suatu pertanyaan kepada masyarakat bahwa kita diperbolehkan membuat perjanjian yang berupa dan berisi apa aja (atau tentang apa-apa) dan perjanjian itu akan mengikat mereka yang membuatnya seperti suatu undang-undang. ${ }^{9}$

2. Asas Konsensualisme dapat disimpulkan dalam pasal 1320 ayat (1) BW, yang berbunyi : "Untuk sahnya suatu perjanjian diperlukan (4) empat syarat":

a. Sepakat mereka yang mengikat dirinya

b. Kecakapan untuk membuat suatu perjanjian

c. Suatu hal tertentu

d. Suatu sebab yang halal.

Arti asas konsensualisme adalah pada dasarnya perjanjian dan perikatan yang timbul karenanya itu sudah dilahirkan sejak detik tercapainya kesepakatan. Dengan perkataan lain, perjanjian itu sudah sah apabila sudah sepakat mengenai hal-hal yang pokok dan tidaklah diperlukan sesuatu formalitas. Oleh karena dalam pasal tersebut tidak disebutkan suatu formalitas tertentu disamping kesepakatan yang telah tercapai itu maka disimpulkan bahwa setiap perjanjian itu sudahlah sah (dalam arti mengikat) apabila sudah tercapai kesepakatan mengenai hal-hal yang pokok dari perjanjian itu. ${ }^{10}$

\footnotetext{
7 ibid.[6].

8 ibid.[2].

9 Subekti, Hukum Perjanjian (Intermasa 2002).[13-14].

${ }^{10}$ R. Subekti, Hukum Perjanjian (Intermasa 1992).[15].
} 
3. Asas Pacta Sun Servanda disebut juga dengan asas kepastian hukum. Asas ini berhubungan dengan akibat perjanjian asas pacta sun servanda merupakan asas bahwa hakim atau pihak ketiga harus menghormati substansi kontrak yang dibuat oleh para pihak, sebagaimana layaknya sebuah undang-undang. Asas pacta sun servanda dapat ditemui dalam Pasal 1338 ayat (1) BW "Semua perjanjian yang dibuat secara sah berlaku sebagai undang-undang bagi mereka yang membuatnya" ${ }^{11}$

4. Asas Itikad Baik dapat disimpulkan dari pasal 1338 ayat (3) BW yang berbunyi "suatu perjanjian harus dilaksanakan dengan itikad baik". Asas Itikad Baik merupakan asas bahwa para pihak yaitu pihak kreditur dan debitur harus melaksanakan substansi kontrak berdasarkan kepercayaan atau keyakinan yang teguh atau kemauan baik dari para pihak. ${ }^{12}$

5. Asas Personalitas merupakan asas yang menentukan bahwa seseorang yang akan melakukan dan atau membuat kontrak hanya untuk kepentingan perseorangan saja. Hal ini dapat dilihat dalam pasal 1315 dan 1340 BW. Pasal 1315 BW berbunyi "Pada umumnya tak seorang dapat mengikatkan diri atas nama sendiri atau meminta ditetapkannya suatu janji dari pada untuk dirinya sendiri”. Pasal 1340 BW berbunyi : "Suatu perjanjian hanya berlaku antara pihak-pihak yang membuatnya”. Ini berarti bahwa perjanjian yang dibuat oleh para pihak hanya berlaku bagi mereka yang membuatnya. ${ }^{13}$

Kedudukan kontrak dalam transaksi bisnis sangatlah penting, utamanya sebagai sarana untuk memastikan apakah yang hendak dicapai para pihak dapat diwujudkan atau tidak. ${ }^{14}$ Kontrak Kerja Konstruksi sendiri dikenal sebagai kontrak pelaksanaan konstruksi bangunan. Construction Contract diterjemahkan dalam kontrak kerja konstruksi, merupakan kontrak ytang dikenal dalam pelaksanaan konstruksi bangunan, baik yang dilakukan oleh Pemerintah ataupun

\footnotetext{
${ }^{11}$ Salim H, Hukum Kontrak Teori Dan Teknik Penyusunan Kontrak (Sinar Grafika 2003).[11].

12 ibid.[13].

${ }^{13}$ ibid.[12].

${ }^{14}$ Yohanes Sogar Simamora, 'Prinsip Hukum Kontrak Dalam Pengadaan Barang Dan Jasa
} Oleh Pemerintah' (Universitas Airlangga 2005 2005).[27]. 
yang dilakukan oleh swasta. ${ }^{15}$ Dalam Pasal 1 angka 8, Kontrak Kerja Konstruksi didefinisikan sebagai keseluruhan dokumen kontrak yang mengatur hubungan hukum antara Pengguna Jasa dan Penyedia Jasa dalam penyelenggaraan Jasa Konstruksi. Pasal 20 ayat (1) Peraturan Pemerintah Nomor 29 Tahun 2000 tentang Penyelenggaraan Jasa Konstruksi mengatur bahwa Kontrak Kerja Kontruksi pada dasarnya dibuat secara terpisah sesuai tahapan dalam pekerjaan konstruksi untuk pekerjaan perencanaan, kontrak konstruksi untuk pekerjaan pelaksanaan, dan kontrak kerja konstruksi untuk pekerjaan pengawasan. Unsur dalam kontrak kerja konstruksi meliputi:

1. Adanya Subjek, yaitu Pengguna dan Penyedia Barang/Jasa;

2. Adanya Objek, yaitu Konstruksi;

3. Adanya dokumen yang mengatur hubungan antara Pengguna Jasa dan Penyedia Jasa.

Dalam Blacklaws Dictionary, Kontrak Konstruksi didefinisikan sebagai suatu perjanjian atau kontrak yang merencanakan dan khusus untuk konstruksi, yang dibuat sebagai bagian dari perjanjian itu sendiri. ${ }^{16}$ Suatu kesepakatan kehendak merupakan unsur essensial dalam suatu kontrak tidak terkecuali dalam kontrak konstruksi, sehingga untuk mewujudkan suatu pekerjaan konstruksi maka diperlukan suatu kesepakatan kehendak sebagai salah satu syarat sahnya suatu kontrak. Kontrak Kerja Konstruksi merupakan perjanjian tidak bernama karena tidak diatur dalam BW. Pengaturan dalam BW hanya menjangkau Perjanjian Pemborongan sebagaimana diatur dalam Bab VII A Buku III BW. Sebagaimana perjanjian pada umumnya, kontrak kerja konstruksi harus memenuhi 4 (empat) syarat sebagaimana diatur dalam Pasal 1320 BW, yaitu:

1. Kesepakatan Para Pihak;

2. Kecakapan para pihak;

3. Adanya objek tertentu;

4. Suatu sebab yang halal/klausa yang diperbolehkan.

Syarat-syarat yang diatur dalam pasal 1320 BW tersebut terbagi menjadi syarat subjektif yang terdiri dari unsur kesepakatan para pihak dan kecakapan para

\footnotetext{
${ }^{15}$ Salim H.S, Perkembangan Hukum Kontrak Innominaat Di Indonesia (Sinar Grafika 2004).[55].

${ }^{16}$ ibid.[91].
} 
pihak, dan syarat objektif yang terdiri dari unsur adanya objek tertentu dan suatu sebab yang halal/klausa yang diperbolehkan.

Dalam Kontrak Konstruksi masing-masing pihak yaitu Pengguna jasa atau sering dikenal dengan istilah bouwheer, owner employer, buyer, pemberi tugas, yang memborongkan dan Penyedia Jasa atau sering dikenal dengan istilah kontraktor memiliki hak dan kewajiban yang dituangkan dalam kontrak, dimana nantinya disepakati oleh para pihak tersebut hak dan kewajiban yang dituangkan dalam kontrak kerja konstruksi inilah yang nantinya akan ditimbal-balikkan oleh para pihak. Kontrak yang dibuat ini akan menjamin adanya kepastian hukum bagi para pihak yang membuatnya, sehingga para pihak bisa mengetahui apa yang harus diperbuat oleh para pihak. ${ }^{17}$ Kepastian hukum ini berkaitan dengan asas pacta sunt servanda, artinya para pihak harus menghormati substansi kontrak yang dibuat oleh para pihak. ${ }^{18}$ Sebagaimana asas pacta sunt servanda, daya ikat hak dan kewajiban bagi para pihak seperti mengikatnya undang-undang. Sesuai dengan ketentuan Pasal 1338 ayat (2) BW, yaitu "Perjanjian tidak dapat ditarik kembali selain dengan sepakat kedua belah pihak, atau karena alasan-alasan yang oleh undangundang dinyatakan cukup untuk itu”, maka kontrak kerja konstruksi tidak dapat dibatalkan atau diputuskan secara sepihak dan harus dilaksanakan dengan iktikad baik sebagaimana ketentuan Pasal 1338 ayat (3) BW.

Di dalam BW dikenal adanya 2 (dua) macam Perjanjian Pemborongan yaitu: ${ }^{19}$

1. Perjanjian pemborongan dimana pemborong hanya melakukan pekerjaan saja.

2. Perjanjian pemborongan di mana Pemborong selain melakukan pekerjaan juga menyediakan bahan-bahannya (materialnya).

Perbedaan kedua macam perjanjian pemborongan tersebut terletak dalam hal risiko apabilaterjadi Overmacht(keadaan memaksa). Dalam Perjanjian Pemborongan dimana Pemborong hanya melakukan pekerjaan saja, apabila pekerjaan itu musnah

\footnotetext{
${ }^{17}$ Ari Purwadi, 'Prinsip Tanggung Gugat Dari Profesi Perencana Terhadap Kegagalan Pekerjaan Jasa Konstruksi Jalan Tol’ (2014) 10 Jurnal Ilmu Hukum.[109].

18 ibid.[109].

${ }^{19}$ Djumialdji, Hukum Bangunan Dasar-Dasar Hukum Dalam Proyek Dan Sumber Daya Manusia (Rineka Cipta 1996).[8-9].
} 
sebelum diserahkan maka pemborong hanya bertanggungjawab atas kesalahannya saja. Kemudian jika pemborong juga menyediakan bahan-bahan selain melakukan pekerjaannya, apabila pekerjaan itu musnah sebelum diserahkan, maka pemborong bertanggung jawab baik karena kesalahannya maupun bukan karena kesalahannya kecuali jika pihak yang memborongkan telah lalai menerima pekerjaan tersebut.

Pertanggungjawaban para pihak dalam kegagalan bangunan dilihat dari masing-masing jenis kontrak konstruksi. Berdasar pembagian tugas para pihak yang berkontrak, Kontrak Konstruksi memiliki aspek yang dikenal dengan kontrak biasa/Konvensional, kontrak spesialis, Rancang bangun (Turnkey), BOT/BLT, dan swakelola. Kontrak Kontruksi bentuk Konvensional merupakan kontrak tertua yang dikenal di Indonesia dan masih digunakan sampai saat ini. Dalam kontrak ini terdapat pembagian tugas yang sederhana, yaitu Pengguna Jasa menugaskan Penyedia jasa untuk melaksanakan suatu pekerjaan yang sudah dibuat direncananya oleh pihak lain. Bentuk Kontrak Spesialis menggunakan kontrak lebih dari satu kontrak Kontruksi, karena Pengguna Jasa membagi bagi kontrak beberapa buah berdasarkan bidang pekerjaan Khusus/spesial, seperti dalam pekerjaan Proyek gedung bertingkat dengan Teknologi yang cukup kompleks maka Penyedia jasa membagi pengerjaan proyek pada beberapa Penyedia jasa yaitu pekerjaan Fondasi dikontrakkan pada Penyedia Jasa A, pekerjaan bangunan atas diberikan pada Penyedia B, pekerjaan mekanikal dan Elektronikal diserahkan kepada Penyedia C, Pekerjaan Lift diserahkan pada Penyedia Jasa D dan masih banyak lagi pembagian pekerjaan yang lain. Bentuk Kontrak Rancang Bangun (Design contruct/Build/ Turnkey) sering dikenal dengan kontrak Turnkey. Secara teknis kontrak rancang bangun ini lebih jelas dan cepat karena menggambarkan pembagian tugas dalam kontrak tersebut. Kontrak Engineering, Procurement and Contruction (EPC) sebenarnya juga bentuk kontrak rancang bangun yang dikenal dengan Design Build/ Turnkey. Tetapi kontrak EPC ini dimaksudkan untuk pembangunan pekerjaanpekerjaan dalam industri minyak, gas bumi, dan petrokimia. Dalam kontrak ini yang dinilai adalah bukan selesainya pekerjaan melainkan untuk kerja pelaksanaan pekerjaan tersebut. Bentuk Kontrak Build Operate Transfer (BOT / BLT) adalah 
kontrak dimana pihak kontraktor menyerahkan bangunan yang sudah dibangunnya itu setelah masa transfer, sementara sebelum proyek tersebut diserahkan, ada masa tenggang waktu bagi pihak kontraktor atau penyedia jasa (misalnya 20 tahun) yang disebut "masa konsensi" untuk mengoperasikan proyek dan memungut hasil / revenue sebagai imbalan dari jasa membangun proyek yang bersangkutan.

Dalam kaitannya dengan biaya pekerjaan, terdapat 2 (dua) macam bentuk Kontrak Konstruksi yang sering digunakan yaitu Fixed Lump Sum Price dan Unit Price sehingga kontraknya sering dinamakan Kontrak harga pasti dan Kontrak harga satuan dan apabila diperlukan sesuai dengan kondisi dan kebutuhan, maka kedua kontrak ini dapat digabungkan. Kontrak lumsum sendiri lebih dikenal dengan karakternya yang pasti yang harus dibayar oleh pengguna jasa kepada penyedia jasa untuk pelaksanaan seluruh pekerjaan. Penyedia jasa memikul risiko untuk dapat melaksanakan seluruh pekerjaan dengan jumlah biaya tercantum dalam kontrak. Penyedia jasa memperoleh keuntungan dari selisih antara nilai kontrak dan biaya yang dikeluarkan penyedia jasa, termasuk Over Head dan biaya-biaya tidak langsung. Sehingga pada jenis kontrak ini penyedia jasa harus dapat mengantisipasi risiko kenaikan harga dengan menambahkan sejumlah biaya dalam kontrak, dengan arti penyedia jasa mengajukan penawaran dengan mempertimbangkan kondisi terburuk yang mungkin memperngaruhi biaya. Sedangkan kontrak harga satuan cenderung lebih dapat disesuaikan dengan kondisi dan kebutuhan dalam pelaksanaan kontrak. Kontrak Lumsum, sebagaimana dijelaskan dalam Pasal 27 ayat (3) Peraturan Presiden Nomor 16 Tahun 2018 tentang Pengadaan Barang/Jasa Pemerintah memiliki ciri jumlah biaya dan batas waktu yang bersifat tetap dan memiliki ketentuan yaitu :

a. semua risiko sepenuhnya ditanggung oleh Penyedia;

b. berorientasi kepada keluaran; dan

c. pembayaran didasarkan pada tahapan produk/keluaran yang dihasilkan sesuai dengan Kontrak.

Sedangkan yang dimaksud sebagai kontrak Harga Satuan dalam Peraturan Presiden Nomor 16 Tahun 2018 tentang Pengadaan Barang/Jasa Pemerintah 
merupakan kontrak Pengadaan Barang/ Pekerjaan Konstruksi/Jasa lainnya dengan harga satuan yang tetap untuk setiap satuan atau unsur pekerjaan dengan spesifikasi teknis tertentu atas penyelesaian seluruh pekerjaan dalam batas waktu yang telah ditetapkan dengan ketentuan :

a. volume atau kuantitas pekerjaannya masih bersifat perkiraan pada saat Kontrak ditandatangani;

b. pembayaran berdasarkan hasil pengukuran bersama atas realisasi volume pekerjaan; dan

c. nilai akhir kontrak ditetapkan setelah seluruh pekerjaan diselesaikan.

Kedua jenis kontrak ini, yaitu Kontrak Lumsum dan Kontrak Harga Satuan dapat digabungkan dalam satu kontrak kerja konstruksi. Dalam kontrak Lumsum ini Pengguna jasa dan Penyedia Jasa sepakat pada suatu jumlah pasti yang harus dibayar oleh Pengguna jasa kepada Penyedia jasa untuk Pelaksanaan seluruh pekerjaan. Penyedia jasa memikul risiko untuk dapat melaksanakan seluruh pekerjaan dengan jumlah biaya tercantum dalam Kontrak. Keuntungan dari Penyedia Jasa dapat diperoleh, jika terdapat selisih antara nilai Kontrak dan biaya dikeluarkan Penyedia jasa, termasuk Over Head dan biaya-biaya tidak langsung. ${ }^{20}$ pada jenis Kontrak ini Penyedia Jasa harus dapat mengantisipasi risiko kenaikan harga dengan menanamkan sejumlah biaya dalam kontrak, maksudnya adalah Penyedia Jasa mengajukan penawaran dengan mempertimbangkan kondisi terburuk yang mungkin mempengaruhi biaya. Hal ini dikaitkan dengan harga untuk memperoleh pekerjaan melalui proses penawaran rendah. Dalam hal ini pada umumnya Penyedia Jasa membayar harga-harga pasti yang mengarah pada tingkatan-tingkatan maksimum biaya yang diantisipasi, tidak pandang apakah biaya maksimum ini benar terjadi atau tidak. ${ }^{21}$ Kontrak Lumsum ini memiliki kelemahan, yaitu banyaknya pekerjaan pengukuran ulang yang harus dilakukan bersama antara Penyedia Jasa dan Pengguna Jasa untuk menetapkan volume pekerjaan yang benar-benar terlaksana. Disamping itu juga Opname hasil

\footnotetext{
${ }^{20}$ H. Nazarkhan Yasin (n 4).Op.Cit.[22].

${ }^{21}$ ibid.[22].
} 
pekerjaan secara bersama-sama ini menimbulkan peluang Kolusi antara petugas Penyedia jasa dengan petugas Pengguna jasa dan hal tersebut merepotkan jasa karena harus menyediakan tenaga dan biaya lagi untuk melakukan pengukuran ulang Dengan demikian, risiko yang ditanggung oleh pihak Penyedia barang/jasa memang lebih besar dalam jenis kontrak lumsum ini, misalnya volume pekerjaan yang sesungguhnya (setelah diukur ulang) ternyata lebih besar dari pada yang tercantum dalam Kontrak. ${ }^{22}$

Pada jenis Kontrak Harga Satuan (unit price) suatu harga ditetapkan untuk beberapa bagian pekerjaan saja. Contohnya seperti pengecoran beton dengan harga satuan Rp50.000.000,-. Risiko pengguna jasa dengan sistem dengan harga satuan menuntut pemantauan ketat dan vertifikasi terhadap jumlah satuan yang sesungguhnya. Pada jenis Kontrak ini, Penyedia Jasa dibayar suatu jumlah yang pasti untuk setiap satuan pekerjaan yang dilaksanakan. Pada jenis Kontrak Harga Satuan, Pengguna Jasa memperhitungkan risiko dari jumlah pekerjaan yang akan dilaksanakan termasuk perkiraan risiko pekerjaan yang dibuat Pengguna jasa atau risiko pada tahap perencanaan pekerjaan. Walaupun sifatnya perkiraan, tetapi dalam menentukannya harus berusaha dengan maksimal sehingga perkiraan tersebut mendekati titik akurat.

Dalam kaitannya dengan pelaksanakan proyek pembangunan, baik gedung maupun prasarana wilayah khususnya jalan harus didahului dengan prosedur pemilihan atau penunjukan Penyedia jasa, dimana Penyedia jasa ini akan ditunjuk untuk melaksanakan proyek yang telah diberikan oleh Pengguna jasa. Pemilihan Penyedia Barang/Jasa dilakukan dengan cara penunjukan langsung atau tender sebagaimana dijelaskan dalam Pasal 42 Undang-undang Nomor 2 Tahun 2017 Jasa Konstruksi. Bentuk hak dan kewajiban para pihak dalam kontrak kerja konstruksi ditentukan oleh para pihak, sebagaimana prinsip kebebasan berkontrak dalam Pasal 1338 BW.

${ }^{22}$ ibid.[22-23]. 


\section{Kegagalan Bangunan dan Akibat Hukumnya}

Berbagai pengerjaan konstruksi tidak luput dari permasalahan, yang cukup sering terjadi adalah kegagalan bangunan. Pada peraturan sebelumnya, termasuk dalam Peraturan Pemerintah Nomor 29 tahun 2000 yang merupakan peraturan pelaksana dari Undang-undang Nomor 18 Tahun 1999 tentang Jasa Konstruksi yang akhirnya dinyatakan tidak berlaku setelah diberlakukannya Undang-undang Nomor 2 Tahun 2019 tentang Jasa Konstruksi, dalam Pasal 31-nya terdapat istilah Kegagalan Konstruksi yang didefinisikan sebagai keadaan hasil pekerjaan konstruksi yang tidak sesuai dengan spesifikasi pekerjaan sebagaimana disepakati dalam kontrak kerja konstruksi baik sebagian maupun keseluruhan sebagai akibat dari kesalahan Pengguna Jasa atau Penyedia Jasa. Namun, dalam Undang-undang Nomor 2 Tahun 2017 tentang Jasa Konstruksi tidak ada lagi istilah kegagalan Konstruksi, tetapi yang ada hanyalah istilah Kegagalan Bangunan.

Kegagalan bangunan yang timbul karena kesalahan Kontraktor pelaksana yaitu pada masa pelaksanaan pengerjaan proyek merupakan akibat dari penyimpangan ketentuan standarisasi dan perencanaan yang dibuat oleh Konsultan Teknik proyek. Kemudian kegagalan bangunan menurut ketentuan Pasal 34 Peraturan Pemerintah Nomor 29 tahun 2000 adalah keadaan bangunan yang tidak berfungsi, baik secara keseluruhan maupun sebagian dari segi teknis, manfaat, keselamatan, dan kesehatan kerja atau keselamatan umum sebagai akibat kesalahan Penyedia Jasa dan atau Pengguna jasa setelah penyerahan akhir pekerjaan konstruksi. Dengan melihat pengertian tersebut maka kegagalan bangunan terjadi pada waktu setelah penyerahan akhir pekerjaan atau juga tahap penyerahan kedua proyek, berarti sudah melampaui batas waktu proyek. Bentuk fisik dari kegagalan bangunan sebenarnya tidak ada perbedaan dengan bentuk fisik kegagalan konstruksi, hanya perbedaan terletak pada waktu terjadinya. Bangunan yang mengalami gagal fungsi sebelum akhir umur pemakaiannya yang direncanakan termasuk dalam kegagalan bangunan. Bangunan yang berefek buruk terhadap lingkungan sekitarnya bias karena kesalahan dalam konsep desain, walaupun pelaksanaannya benar, itupun termasuk dalam 
kegagalan bangunan juga. ${ }^{23}$

Kegagalan Bangunan sendiri dalam Pasal 1 angka 10 Undang-undang Nomor 2 Tahun 2017 tentang Jasa Konstruksi didefinisikan sebagai adalah suatu keadaan keruntuhan bangunan dan/atau tidak berfungsinya bangunan setelah penyerahan akhir hasil Jasa Konstruksi. Konteks kegagalan bangunan dalam tulisan ini adalah kegagalan bangunan yang disebabkan kesalahan dari Kontraktor, misalnya kegagalan bangunan tersebut akibat dari penyimpangan ketentuan standarisasi dan perencanaan yang dibuat oleh Konsultan tekhnik proyek.

Sebagaimana definisi kegagalan bangunan dalam Pasal 1 angka 10 Undangundang Nomor 2 Tahun 2017 tentang Jasa Konstruksi, maka kegagalan bangunan mulai dihitung sejak penyerahan akhir pekerjaan kepada pihak Pengguna jasa. Kegagalan bangunan adalah risiko yang tidak berdiri sendiri, selalu ada sebab akibat yang menyertainya, tanggung jawab harusnya dipikul bersama-sama. Kegagalan pekerjaan konstruksi dapat disebabkan oleh faktor teknis maupun faktor non-teknis. ${ }^{24}$ Faktor teknis karena adanya penyimpangan proses pelaksanaan yang tidak memenuhi spesifikasi teknis yang disepakati dalam kontrak, sedangkan faktor non-teknis lebih disebabkan karena tidak kompetennya Badan Usaha, tenaga kerja, tidak profesionalnya tata kelola manajerial antara pihak-pihak yang terlibat dalam proyek konstruksi. ${ }^{25}$ Serta bisa jadi terdapat permasalahan timbul karena hal nonteknis yang mengakibatkan kegagalan teknis. Komunikasi yang tidak terjalin dengan baik ada kalanya menyebabkan kesalahan fatal. Untuk menetapkan apakah benar kegagalan bangunan yang terjadi disebabkan oleh kesalahan Kontraktor atau bukan, berdasar ketentuan dalam Pasal 60 Undangundang Nomor 2 Tahun 2017 tentang Jasa Konstruksi mengatur bahwa yang berhak menilai terkait kegagalan bangunan adalah ahli yang memiliki kompetensi

\footnotetext{
${ }^{23}$ Dinas Pekerjaan Umum \& Penataan Ruang, 'Kegagalan Bangunan Tiada Lagi Pidana Bagi Pelaku Jasa Konstruksi' (Kabupaten Indragiri Hilir, 2019) < http://pupr.inhilkab.go.id/berita/detail/ kegagalan-bangunan> accessed 1 September 2019.

${ }^{24}$ Kusumo Dradjad Sutjahjo dan Setiyadi, 'Aspek Hukum Terhadap Kegagalan Pelaksanaan Pekerjaan Konstruksi Proyek Di Jakarta’ (2016) 15 Politeknologi.[2].

${ }^{25}$ ibid.[2].
} 
tertentu yang ditetapkan oleh menteri dalam jangka waktu 30 (tiga puluh) hari sejak diterimanya laporan adanya kegagalan bangunan. Bentuk kegagalan bangunan tak selalu runtuh seluruhnya, tetapi juga bisa karena tidak berfungsinya bangunan yang telah dibangun oleh Kontraktor.

Mengenai penilaian kegaggalan konstruksi ditinjaui dari aspek teknis maupun aspek hukum terletak pada waktu terjadinya. Masa waktu kegagalan bangunan yaitu terjadi pada tahap masa pelaksanaan pekerjaan konstruksi berlangsung sedangkan kegagalan bangunan terjadi pada waktu setelah penyerahan terakhri pekerjaan konstruksi. Perihal kegagalan bangunan waktu terjadinya pada saat setelah penyerahan akhir pekerjaan sampai pada masa pemeliharaan bangunan berakhir, dan pihak yang dapat mengajukan gugatan adalah pengguna jasa dan pemakai bangunan karena kegagalan bangunan sudah menyentuh pada kualitas manfaat yang dihasilkan dari bangunan. Sehingga klausula tanggung gugat kegagalan bangunan dalam kontrak konstruksi harus mencantumkan terpisah dari klausula tanggung gugat kegagalan bangunan. Perbedaan ciri pada kegagalan bangunan dan kegaggalan konstruksi berbeda dengan klausula kegagalan bangunan dan harus ditegaskan dalam kontrak konstruksi.

Dalam hal terjadinya kegagalan bangunan, maka Penilai ahli memiliki fungsi utama yaitu berwenang untuk menyatakan adanya kegagalan bangunan. ${ }^{26}$ Dalam Pasal 61 ayat (1) Undang-undang Nomor 2 Tahun 2017 tentang Jasa Konstruksi mengatur bahwa yang dikategorikan sebagai Ahli yang berwenang untuk menyatakan adanya kegagalan bangunan adalah individu yang memiliki kriteria sebagai berikut :

a. memiliki Sertifikat Kompetensi Kerja pada jenjang jabatan ahli di bidang yang sesuai dengan klasifikasiproduk bangunan yang mengalami Kegagalan Bangunan;

b. memiliki pengalaman sebagai perencana, pelaksana,dan/atau pengawas pada Jasa Konstruksi sesuai dengan klasifikasi produk bangunan yang mengalami Kegagalan Bangunan; dan

\footnotetext{
${ }^{26}$ Sarwono Hardjomuljadi, 'Peran Penilai Ahli Dalam Penanganan Kegagalan Bangunan Dan Kegagalan Konstruksi (Menurut UU No. 18 Tahun 1999 Jo. PP 29 Tahun 2000)’ (2014) 6 Konstruksia.[7].
} 
c. terdaftar sebagai penilai ahli di kementerian yang menyelenggarakan urusan pemerintahan di bidang Jasa Konstruksi.

Dalam ketentuan Pasal 61 ayat (2) Undang-undang Nomor 2 Tahun 2017 tentang Jasa Konstruksi dijelaskan bahwa Ahli yang berwenang untuk menyatakan adanya kegagalan bangunan memiliki tugas yang meliputi:

a. menetapkan tingkat kepatuhan terhadap Standar Keamanan, Keselamatan, Kesehatan, dan Keberlanjutan dalam penyelenggaraan Jasa Konstruksi;

b. menetapkan penyebab terjadinya Kegagalan Bangunan;

c. menetapkan tingkat keruntuhan dan/atau tidak berfungsinya bangunan;

d. menetapkan pihak yang bertanggung jawab atas Kegagalan Bangunan;

e. melaporkan hasil penilaiannya kepada Menteri dan instansi yang mengeluarkan izin membangun, paling lambat 90 (sembilan puluh) hari kerja terhitung sejaktanggal pelaksanaan tugas; dan

f. memberikan rekomendasi kebijakan kepada Menteri dalam rangka pencegahan terjadinya Kegagalan Bangunan.

Dalam kontrak konstruksi terdapat syarat kesepakatan atau consensus para pihak yang dituangkan dalam suatu perjanjian. Tanggung gugat yang dapat dilakukan para pihak terutama penyedia jasa terhadap kegagalan bangunan adalah tanggung gugat yang didasari adanya wanprestasi, karena pihak penyedia jasa tidak memenuhi atau lalai melaksanakan keajiban sebagaimana yang telah ditentukan dalam perjanjian yang disepakati para pihak dan telah menimbulkan kerugian terhadap salah satu pihak. Wanprestasi juga disebut sebagai ingkar janji, atai juga melanggar perjanjian, dan bila penyedia jasa telah melakukan atau berbuat sesuatu yang tidak boleh dilakukannya. ${ }^{27}$

Wanprestasi (kelalaian atau kealpaan) yang dilakukan oleh penyedia jasa dapat berupa 4 macam, yaitu: ${ }^{28}$

a. tidak melakukan apa yang disanggupi dan dilakukannya;

b. melaksanakan apa yang telah dijanjikan, tapi tidak sebagaimana yang telah dijanjikan;

c. melakukan apa yang dijanjikannya tetapi terlambat;

d. melakukan sesuatu yang menurut perjanjiannya tidak boleh dilakukan.

Dalam kontrak jasa konstruksi penyedia jasa / kontraktor pelaksana dapat dikatakan

\footnotetext{
${ }^{27}$ Subekti (n 9).Op.Cit.[45].

${ }^{28}$ ibid [45].
} 
wanprestasi jika telah lalai atau ingkar janji dalam hal :

a. Persyaratan;

b. Kualitas; dan/atau

c. Waktu.

Terjadinya wanprestasi pihak penyedia jasa / kontraktor pelaksana dalam suatu perjanjian atau yang disebut dengan Debitur, membawa akibat bagi penyedia jasa tersebut, antaralain: ${ }^{29}$

a. Mengganti kerugian;

b. Benda yang menjadi objek perikatan semenjak terjadi wanpresatsi menjadi tanggung gugat penyedia jasa atau debitur;

c. Jika perikatan tersebut timbul dari perikatan timbal balik, pengguna jasa atau kreditur dapat meminta pembatalan (pemutusan) perjanjian.

Untuk melihat ada tidaknya kesalahan atau kelalaian yang dilakukan oleh kontraktor dalam suatu kegagalan bangunan dapat dilihat pada ketidak patuhan terhadap metode kerja yang benar dan sesuai dengan aturan yang berlaku. Dalam ketentuan Pasal 63 Undang-undang Nomor 2 Tahun 2017 tentang Jasa Konstruksi dijelaskan bahwa Penyedia Jasa wajib mengganti atau memperbaiki Kegagalan Bangunan kesalahan Penyedia Jasa. Dengan demikian, pendapat Ahli sebagaimana yang diatur dalam Pasal 60 Undang-undang Nomor 2 Tahun 2017 tentang Jasa Konstruksi amatlah penting. Hal ini ditujukan untuk menilai apakah benar kegagalan bangunan tersebut terjadi karena kesalahan Kontraktor atau kesalahan perencanaan. Apabila kegagalan bangunan terjadi karena kesalahan perencanaan atau kesalahan Pengguna Jasa, maka Pengguna jasalah yang harus bertanggung jawab, sebagaimana ketentuan dalam Pasal 60 ayat (1) Undang-undang Nomor 2 Tahun 2017 tentang Jasa Konstruksi. Sehingga dalam hal ini, penyusunan kontrak harus disusun dengan sangat baik dan mekanisme pembuktian harus dijalankan dengan baik. Namun, dalam hal jenis kontrak adalah lumsum, maka biasanya para pihak akan menuangkan klausul yang intinya adalah apabila terjadi risiko termasuk

\footnotetext{
${ }^{29}$ Purwadi Patrik, Dasar-Dasar Hukum Perikatan (Perikatan Yang Lahir Dari Perjanjian Dan Dari Undang-Undang) (Mandar Maju 1994).[1].
} 
kegagalan bangunan, maka yang akan menanggung risiko tersebut adalah pihak kontraktor. Dengan demikian, sesuai dengan ketentuan Pasal 27 ayat (3) Peraturan Presiden Nomor 16 Tahun 2018 tentang Pengadaan Barang/Jasa Pemerintah, maka kontraktor yang harus bertanggung gugat atas kegagalan bangunan yang terjadi dalam kontrak jenis Lumsum.

Untuk melakukan tanggung gugat, maka perlu pengajuan gugatan oleh pihak yang dirugikan dimana dalam hal ini yang dirugikan adalah pengguna jasa. Terhadap hal tersebut, pengguna jasa dapat menuntut atas dasar wanprestasi kepada peyedia jasa sebagai berikut:

a. Pengguna jasa dapat meminta pemenuhan prestasi saja dari penyedia jasa;

b. Pengguna jasa dapat menuntut prestasi disertai ganti rugi kepada penyedia jasa (pasal $1267 \mathrm{BW)}$

c. Pengguna jasa dapat menuntut dan meminta ganti rugi, hanya mungkin kerugian karena keterlambatan;

d. Pengguna jasa dapat melakukan pembatalan perjanjian;

e. Pengguna jasa dapat melakukan pembatalan disertai ganti rugi kepada penyedia jasa, ganti rugi itu berupa pembayaran denda.

Tujuan gugatan wanprestasi adalah untuk memposisikan penggugat dalam keadaan seandainya perjanjian tersebut terpenuhi, dalam arti posisi para pihak seperti dalam keadaan semula yaitu menyepakati dan menjalankan hak dan kewajibannya sebagaimana yang didasari dengan itikad baik. Dengan demikian ganti rugi tersebut adalah berupa kehilangan keuntungan yang diharapkan.

Pelaksanaan ganti rugi sendiri dapat dilakukan melalui mekanisme pertanggungan yang pemberlakuannya disesuaikan dengan tingkat pengembangan sistem pertanggungan bagi perencana dan pengawas konstruksi. ${ }^{30}$ Pertanggungjawaban pelaksana konstruksi di bidang usaha dikenakan kepada pelaksana konstruksi maupun sub pelaksana konstruksi dalam bentuk sanksi administrasi sesuai tingkat kesalahan. ${ }^{31}$ Besaran ganti rugi yang menjadi tanggung jawab pelaksana konstruksi dalam hal terjadi kegagalan hasil pekerjaan konstruksi

${ }^{30}$ Peter Miquel Samuel, 'Tanggung Jawab Penyedia Jasa Menurut Undang-Undang Nomor 18 Tahun 1999 Tentang Jasa Konstruksi’ (2016) 4 Lex Et Societatis.[30].

${ }^{31}$ ibid. [30]. 
diperhitungkan dengan mempertimbangkan antara lain tingkat kegagalannya. ${ }^{32}$ Pelaksanaan ganti rugi dapat dilakukan melalui mekanisme pertanggungan yang pemberlakuannya disesuaikan dengan tingkat pengembangan sistem pertanggungan bagi pelaksana konstruksi. ${ }^{33}$

\section{Kesimpulan}

Pada ketentuan hukum di Indonesia, khususnya Undang-undang Nomor 2 Tahun 2017 tentang jasa konstruksi telah diatur tentang kontrak kerja konstruksi. Dalam pengaturan di Undang-undang Nomor 2 Tahun 2017 tentang jasa konstruksi tersebut juga telah dijelaskan terkait kegagalan bangunan. Dalam hal terjadi kegagalan bangunan, maka harus dilihat kembali kegagalan tersebut disebabkan atas kesalahan siapa. Namun, apabila jenis kontrak yang digunakan adalah kontrak Lumsum yang berarti pihak Kontraktor menerima untuk menanggung segala risiko yang terjadi, maka kontraktor yang harus bertanggung gugat atas kegagalan bangunan yang terjadi sesuai dengan ketentuan Pasal 27 ayat (3) Peraturan Presiden Nomor 16 Tahun 2018 tentang Pengadaan Barang/Jasa Pemerintah.

\section{Daftar Bacaan}

\section{Buku}

Djumialdji, Hukum Bangunan Dasar-Dasar Hukum Dalam Proyek Dan Sumber Daya Manusia (Rineka Cipta 1996).

H. Nazarkhan Yasin, Mengenal Kontrak Konstruksi Di Indonesia (Gramedia 2006).

H.S S, Perkembangan Hukum Kontrak Innominaat Di Indonesia (Sinar Grafika 2004).

H S, Hukum Kontrak Teori Dan Teknik Penyusunan Kontrak (Sinar Grafika 2003).

Hasanuddin Rahman, Contract Drafting (Citra Aditya Bhakti 2003).

Purwadi Patrik, Dasar-Dasar Hukum Perikatan (Perikatan Yang Lahir Dari

\footnotetext{
${ }^{32}$ ibid. [30].
}

${ }^{33}$ ibid.[30]. 
Perjanjian Dan Dari Undang-Undang) (Mandar Maju 1994).

R. Subekti, Hukum Perjanjian (Intermasa 1992).

Simamora YS, 'Prinsip Hukum Kontrak Dalam Pengadaan Barang Dan Jasa Oleh Pemerintah' (Universitas Airlangga 2005 2005).

Subekti, Hukum Perjanjian (Intermasa 2002).

\section{Laman}

Dinas Pekerjaan Umum \& Penataan Ruang, 'Kegagalan Bangunan Tiada Lagi Pidana Bagi Pelaku Jasa Konstruksi' (Kabupaten Indragiri Hilir, 2019) $<$ http://pupr.inhilkab.go.id/berita/detail/kegagalan-bangunan $>$ accessed 1 September 2019.

\section{Perundang-undangan}

Undang-Undang Nomor 18 Tahun 1999 tentang Jasa Konstruksi (Lembaran Negara Republik Indonesia Tahun 1999 Nomor 54, Tambahan Lembaran Negara Republik Indonesia Nomor 3833).

Undang-undang Nomor 2 Tahun 2017 tentang Jasa Konstruksi (Lembaran Negara Tahun 2017 Nomor 11, Tambahan Lembaran Negara Republik Indonesia Nomor 6018).

\section{Peraturan Pemerintah}

Peraturan Pemerintah Nomor 29 Tahun 2000 tentang Penyelenggaraan Jasa Konstruksi (Lembaran Negara Tahun 2000 Nomor 64).

\section{Peraturan Presiden}

Peraturan Presiden Nomor 16 Tahun 2018 tentang Pengadaan Barang/Jasa Pemerintah (Lembaran Negara Tahun 2018 Nomor 33).

HOW TO CITE: Yushar, 'Tanggung Gugat Kontraktor dalam Kegagalan Bangunan’ (2019) Vol. 2 No. 3 Media Iuris. 